\title{
APPLICATION OF ROCK MASS CLASSIFICATION TO EVALUATE ROCK PROPERTIES, NW HIMALAYAS, PAKISTAN
}

\author{
Muhammad BASHARAT 1) *, Amir Farid KHAN 1), \\ Muhammad Tayyib RIAZ ${ }^{1,3)}$ and Rakhshanda SADAF ${ }^{2)}$ \\ 1) Institute of Geology, University of Azad Jammu and Kashmir, Muzaffarabad, Pakistan \\ 2) Department of Geology, Federal Urdu University, Karachi, Pakistan \\ 3) Department of Geology, University of Azad Jammu and Kashmir, Neelum Campus, Athmuqam, Pakistan
}

*Corresponding author's e-mail: basharatgeo@yahoo.com

\begin{tabular}{l}
\hline ARTICLE INFO \\
\hline Article history: \\
Received 4 May 2020 \\
Accepted 19 October 2020 \\
Available online 5 November 2020 \\
\hline
\end{tabular}

Keywords:

Rock Mass

Geological Strength Index

Yadgar Section

Sub-Himalayas

Pakistan

\begin{abstract}
The rock units of the NW Himalayan region are fragile, heavily fractured and highly deformed due to active tectonics and complex geological setup. Fast urbanization, road constructions along hill slopes and other infrastructural development activities also increased the slopes instability problems. The present study emphasizes the application of rock mass classification to estimate the rock mass properties along the Yadgar section Muzaffarabad, NW Himalayas, Pakistan. For this purpose, Rock Mass Rating (RMR) and Geological Strength Index (GSI) were used to characterize and classify the rock masses. In the present study, twenty-five sites have been investigated to evaluate rock properties along the Muzaffarabad-Neelum road, Sub-Himalayas, Pakistan. Result of the study shows that the Abbottabad Formation of Cambrian age is vulnerable in the Yadgar section with extremely poor RQD (Rock Quality Designation), lowest UCS (Unconfined Compression Strength) values and closely spaced discontinuities. RMR values of the Abbottabad Formation ranges from 40-54 and classified as Poor to Fair having low GSI (20 $\pm 3-35 \pm 3$ ), blocky, disintegrated structure. The Paleocene Hangu Formation has lowest GSI (28 $\pm 3-29 \pm 3$; Blocky, Disturbed/ Seamy in nature) having RMR (40-45) and Eocene Kuldana Formation has GSI (30 $\pm 3-$ 45 \pm 3 ; Blocky) having RMR (34-67), are categorized as heavily broken, disintegrated and poorly interlocked rock masses. RMR values of rock units of the Paleocene Lockhart Formation (52-60), the Miocene Murree Formation (38-63), and the Eocene Margala Hill Limestone (38-61) are relatively higher values of GSI ranges from $(35 \pm 3-45 \pm 3 ; 35 \pm 3-50 \pm 3 ; 30 \pm 3-40 \pm 3$ ) respectively. RMR and GSI values in Yadgar section, ranges between 34-67 and 20 $\pm 3-50 \pm 3$ respectively. Analysis shows positive correlation between GSI and RMR values. This approach to evaluate the rock mass classification through RMR and GSI will give the better estimation of rock mass properties along Muzaffarabad-Neelum road to identify the vulnerable slopes and design effective geotechnical measures.
\end{abstract}

\section{INTRODUCTION}

In high land topography of the Himalayas, road and highway network assumes a dynamic part in transport of separated ranges, public networking administration, armed activities and economic welfare of the region. The Himalayan area is structurally dynamic zone described by a structure of thrusted sheets (Kumar, 1971). Slope failures in Himalayan region along road cut sections are frequent and common problem which poses great threat to human life as well as socio-economic developments (Singh et al., 2020; Ansari et al., 2019; Solanki et al., 2019; Gupta et al., 2016; Mahanta et al., 2016). Characteristics of rock mass along the main road is key concern issue in inclined series. Any type of the slope failure in route may initiate inconvenience in activity and also leads to major losses like property and lives etc. Slope failure, characteristics of rock-mass, subsurface water conditions and shear zones are the engineering geology related issues that show up amid the uncovering (Bhatta, 2006). Roads constructed in the hilly areas along the river bank are vulnerable due to tectonic activity, and river cuttings, directly depending on the rock mass properties such as Rock Mass Rating (RMR), and Geological Strength Index (GSI). Therefore, slopes along the riverbanks and road turns need to be characterized for their condition and stability. Several researchers adopted different techniques to evaluate the stability analysis e.g., Singh et al. (2020) performed analytical and numerical stability analysis along road cut sections in Indian Himalaya. Ansari et al. (2019) also performed empirical slope stability analysis along road in lesser Himalayas. Bar et al. (2017), used Q slope method for assessing the excavated rock slopes stability in the field. Singh et al. (2013), performed geotechnical and geophysical surveys to estimate the slope stability conditions more precisely as compared to traditional 
techniques by developing new slope mass rating. Disastrous earthquake of 2005 in the northern parts of Pakistan triggered many thousand landslides particularly in poor rock mass regions, resulting massive life losses (Petley et al., 2006). Detailed understanding of characteristics of rock features and rock mass quality can mitigate such risks activated by natural disasters. An enormous amount of rock mass is involved for the development of roads, engineering structures and underground excavations for the construction purposes.

There are various methods available to characterize and classify such extensive volume of rocks, recognized as geo-mechanical classification. RMR presented by Bieniawski (1989) is based on field and laboratory study and site slope characteristic data. Alternative technique is GSI (Hoek and Brown, 1997; Hoek et al., 1989) which proposes the outline for the assessment of rock mass quality in different geological conditions and is further demonstrated by (Sonmez and Ulusay, 1999). Estimations of GSI are associated with fracture surface conditions and degree of fracturing. The rock mass behavior is governed by intact rock properties and discontinuity pattern of rocks (Sen and Bahaaeldin, 2003).

Kim et al. (2007), suggests a method for block size determination considering persistence to accurately apply GSI system of classification and support the concept of equivalent block size proposed by Cai et al. (2004).

A quantitative approach employing block volume and joint condition factor to assist in the use of the GSI system is presented by (Cai et al., 2004), which adds quantitative means to facilitate use of the system.

Russo (2009), developed a new hybrid quanitative approach for GSI estimation of rock mass by calculating the Joint Parameter (Jp) for Rock Mass Index (RMi) estimation.

Hoek et al. (2013) followed the joint condition rating of Rock Mass Rating (RMR) proposed by Bieniawski (1989) for surface condition and RQD for blockiness calculation. Winn and Wong (2019) studied rock mass properties of tunnel faces to obtainthe quantitative GSI.

Vásárhelyi and Bögöly (2019), present a new method for calculating the GSI value, using the "integral-geometric method". It provides another calculation method of the GSI value that broadens the range of the determination of GSI in case of poor rock mass.

Hoek and Brown (2019), present an update which introduces relatively few fundamental changes, but it does discuss many of the issues of utilization and presents case histories to demonstrate practical applications of the criterion and the GSI system.

Quality of the rock mass achieved through shear strength of surface discontinuities, often depends on more than one element. Such key elements include, placement direction, discontinuity spacing, persistence, characteristics of the surface, aperture of discontinuity, related width and nature of the filled material (if shows) etc. The northern parts of Pakistan and Kashmir region came into focus of worldwide geoscientific group after the 8 October 2005 Kashmir earthquake which devasted the Balakot, Bagh, Muzaffarabad cities, and abutting areas. Thousands of people lost their lives in a few seconds with many more left behind as injured and homeless. Adjecent areas of Muzaffarabad, Yadgar section have been selected for the evaluation of rock mass properties because the area was adversaly affected by the October 8, 2005 earthquake.

Concentrated area of the Yadgar section lies in the territory of the Muzaffarabad situated in the core of the Hazara Kashmir Syntaxis (HKS; Fig. 1). Most part of this section contains sedimentary rocks. The Precambrian to Cenozoic rocks are uncovered in the area. These rocks are folded and faulted to frame HKS due to Himalayan orogeny (Wadia, 1928, 1931; Baig and Lawrence, 1987). Instability of slopes, sheared, fractured rocks and rock mass condition are the real engineering issues experienced in the road broadening and development of the area associated with SubHimalayas, Pakistan.

The study area is located in the tectonically active region of the northwestern Himalayas, Pakistan. The area has got prime focus of numerous researchers however, their work is generally restricted to geology, stratigraphy and structure. As such, no considerable work has been done with regard to engineering geological perspective. In these hilly areas, slope failure causes disturbance of routine movement, human causalities, property loss leading to socioeconomic de-gradation. Unplanned excavation of rock slope for development reasons, destabilizes slopes which critically depends on rock mass behavior. The appropriate solution is Rock Mass classification, with the quantifiable parameters for example RMR, Q-classification and GSI. Aforesaid in view, assessment of rock mass properties and characterization in the Yadgar area, utilizing RMR and GSI classification systems, is considered vital.

Keeping the view of the rock mass strength problem, the RMR and GSI classification systems have been used to evaluate the rock masses properties of the Yadgar section, Muzaffarabad, Kashmir region. The study will serve as the bench mark for engineering classification of rocks in the Yadgar area, including development and their stability analysis for all such engineering ventures in the future.

\section{GEOLOGICAL SETTING}

Rocks of Precambrian to recent age are found in the study area out of which majority has sedimentary origion (Fig. 2). Large exposures found at the Yadgar area. The dolomites are thin to thick bedded in the Yadgar section. Thickness of the Cambrian age Muzaffarabad Formation is about 800 meters to the upper east of Muzaffarabad (Calkins et al., 1975). On 


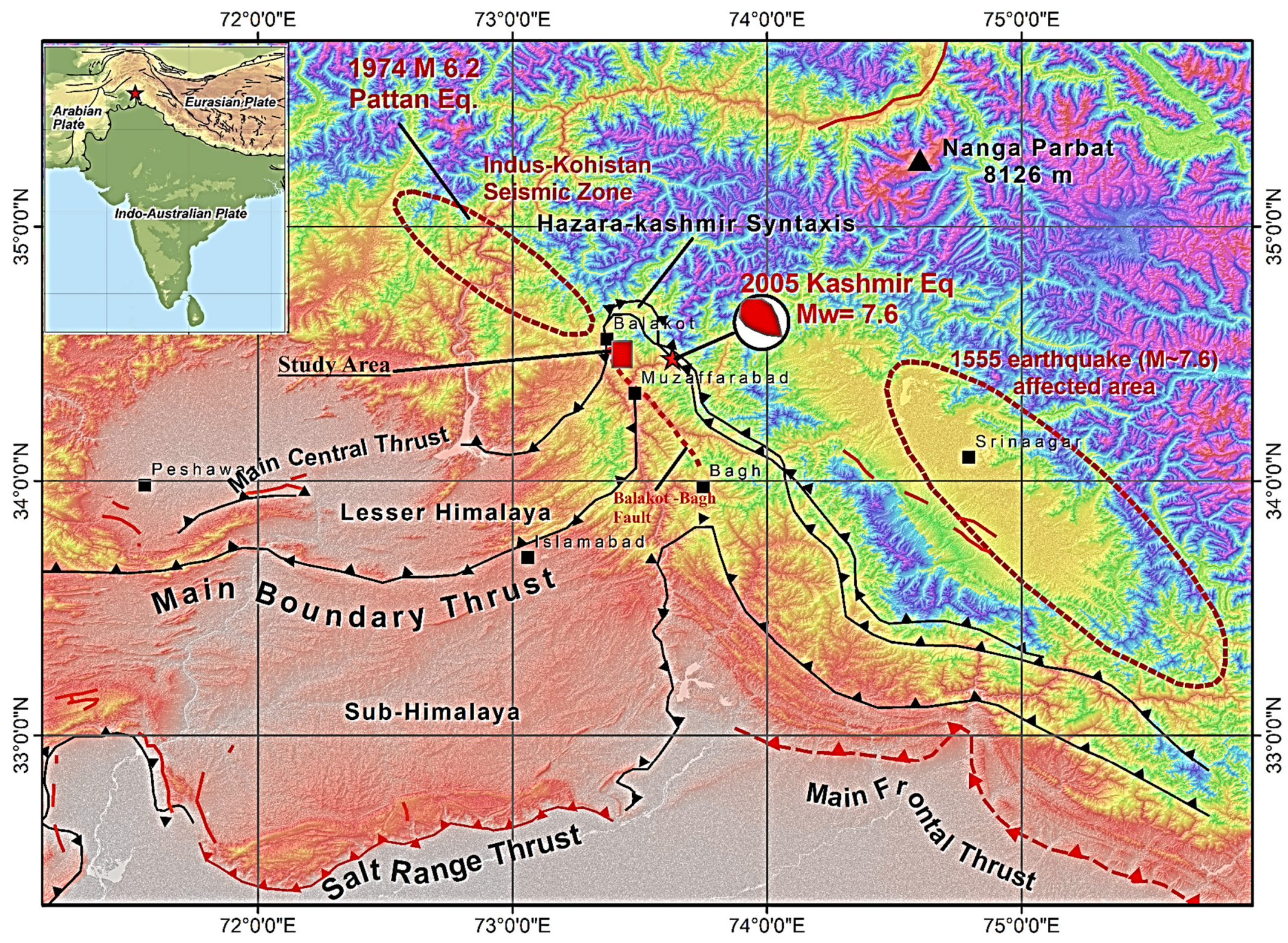

Fig. 1 Regional tectonic map of the frontal Himalayas. (Data from Armbruster et al. 1978; Seeber and Armbruster, 1979; Nakata et al., 1991; Ambraseys and Jackson, 2003; Avouac et al., 2006). 

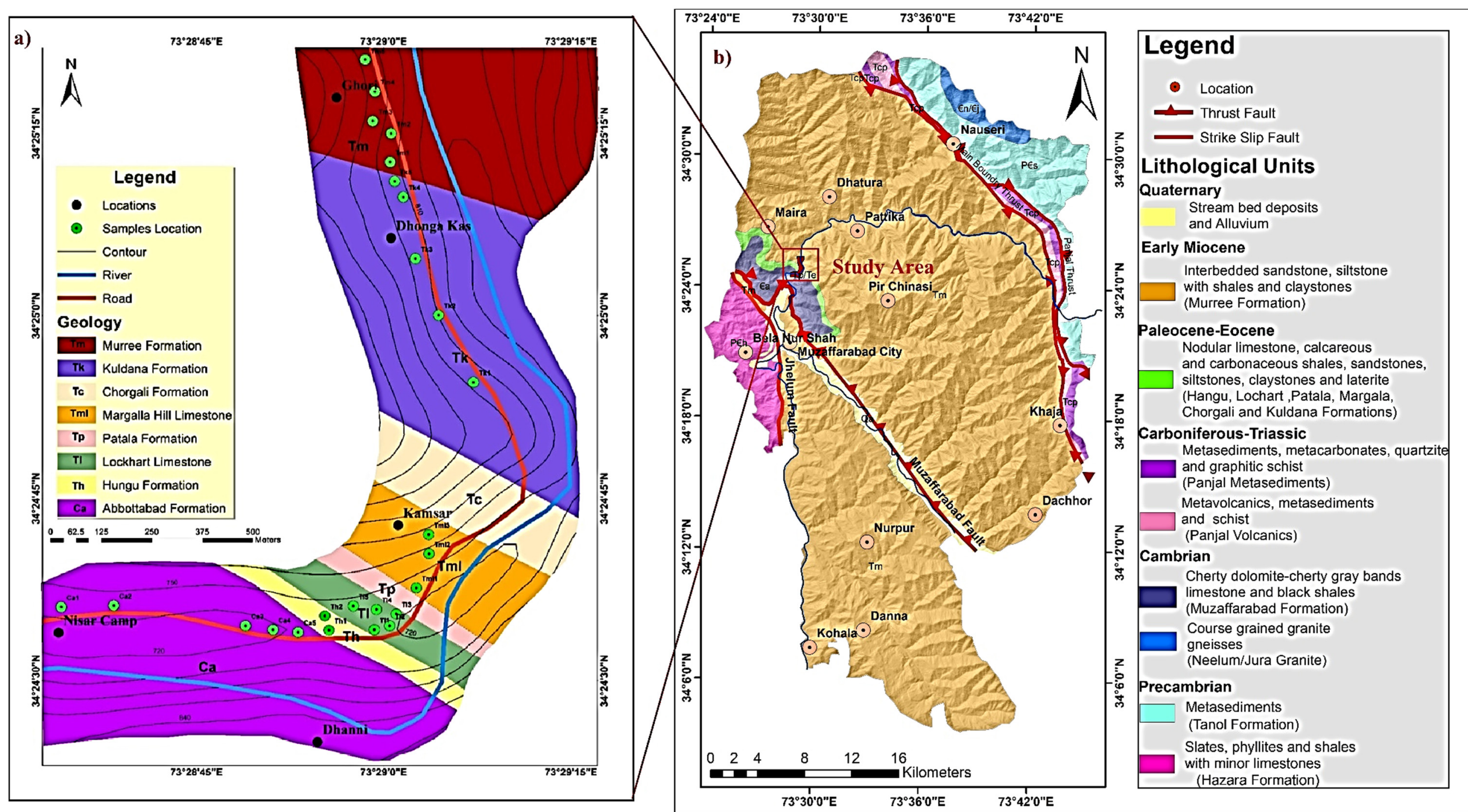

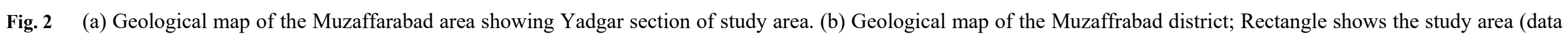
from Riaz et al., 2018). 
the eastern side of the Muzaffarabad City, the Abbotabad Formation is highly crushed and sheared owing to the dynamic fault activity in the region. The rock units found in the study area are; Cambrian Muzaffarabad Formation, Paleocene-Eocene sequence (Hangu Formation, Lockhart Limestone, Patala Formation, Margala Hill Limestone, Chorgali Formation, Kuldana Formation), Miocene Murree Formation and Recent Alluvium (Fig. 2a). Depositional environment of the Murree Formation is cyclic which is determined amid Himalayan-orogeny. Himalayan fore deep comprises of eroded sediments from Himalayan orogenic belt. The northern part of the Indian plate consists of carbonates and clastic rocks. The fore-land basin and Main Boundary Thrust (MBT) have a curvature like hairpin bend around the Hazara and Azad Jammu and Kashmir (AJK) from northwest to southwest and then towards south. On a regional scale, this antiformal structural bend is known as NW Himalayan Syntaxis (Wadia 1931), later on also named as HKS by other researchers (Calkins et al., 1975; Baig and Lawrence, 1987; Bossart et al., 1988; Greco, 1991; Kazmi and Jan, 1997; Rustam et al., 2003). Unlike the classical anticlines, the HKS reveals younger rock units in core section, whereas older rock units are associated with the limbs. This causes stacking of crust because of thrusting prior to the formation of the HKS. Limbs of the HKS are folded by the Panjal Thrust (PT) and the MBT. The MBT, PT, Jhelum Fault (JF) and Muzaffarabad Fault (MF) are prominent tectonically active features in the HKS (Armbruster et al., 1978; Baig and Lawrence, 1987; Yeats et al., 2006). The HKS is shaped due to joining of three autonomously moving structural components; the Himalayas, the shield of Indo-Pakistan and the Salt Range.

HKS represents the unordinary central structure of the syntaxis, whereas, abundant refolding structures are present on the both limbs of syntaxis. HKS comprises of mind-blowing arrangement of over lapping nappes formed by different Precambrian, Paleozoic and Mesozoic developments, which is thrusted on dominating great residue, the Murree Formation of the Miocene age (Bossart et al., 1988).

\section{MATERIAL AND METHODS}

A systematic study was conducted to analyses the nature and behaviour of rock masses in the Yadgar section. Multiple selected locations associated with slopes were considered for the characterization of the rock mass quality. For this purpose, twenty five different locations were identified based on good lithological exposures and the condition of outcrop (Fig. 2a). RMR was determined on the basis of five parameters which include UCS, RQD, ground water condition, spacing of discontinuity and conditions of discontinuity.

At the sampled locations, the UCS was determined in the field by using Schmidt hammer rebound procedure (Fig. 3a). RQD was calculated through condition recommended by Palmstrom (2005), as given in equation 1.

$\mathrm{RQD}=110-2.5 \mathrm{JV}$

Where, $\mathrm{JV}$ is volumetric joint count and characterized by quantity of joint intersects in one cubic meter volume. The associated condition was utilized where joints formed a joint set,

$\mathrm{JV}=1 / \mathrm{S} 1+1 / \mathrm{S} 2+1 / \mathrm{S} 3+\ldots . .1 / \mathrm{Sn}+\mathrm{Nr} / 5$

Here, S1, S2 and S3 represent average spacing between joint sets in meters and $\mathrm{Nr} / 5$, spacing of random joints.

The interpretation of RMR was done by rating estimations of five parameters as mentioned in the equation 3 (Bieniawski, 1989).

$\mathrm{RMR}=\mathrm{R} 1+\mathrm{R} 2+\mathrm{R} 3+\mathrm{R} 4+\mathrm{R} 5$

Where, R1=UCS, R2=RQD, R3=Ground-water condition, R4=discontinuity spacing, and $\mathrm{R} 5=$ discontinuity condition.

Similarly, GSI was estimated by Sonmez and Ulusay (1999), and Bieniawski (1989) criteria. The previous model provides numerical reasons to assessing GSI values with related application of GSI framework while presenting new parameters of evaluations. For example, SCR (Surface Condition Rating) and SR (Structure Rating) depends on JV and RMR parameters which include roughness, weathering and infilling. Scale A shows the surface discontinuity whereas Scale B shows blockiness of rock mass. Key possibility for these scales is Joint Condition (JCond89) rating characterized by Bieniawski (1976) and RQD characterized by Palmstrom (2005). The JCond89 rating relates surface conditions characterized in content blocks of the $\mathrm{x}$ pivot of the GSI diagram.

Scale A is characterized by 1.5 JCond 89 whereas the scale B by RQD/2. The GSI estimations were taken through both scales $\mathrm{A}$ and $\mathrm{B}$, with a relationship.

$\mathrm{GSI}=1.5 \mathrm{JCond} 89+\mathrm{RQD} / 2$

RMR utilizes a similar approach yet unique logscale ratings. After the interpretation of RMR and GSI value, analysis is conducted for geo-mechanical estimations of selected locations with each other. Furthermore, lithology against RMR and GSI were also plotted for the mean estimation of similar rock units.

\section{RESULTS}

\subsection{ROCK MASS RATINGS (RMR) OF LITHOLOGICAL UNITS}

For geomechanical examination, outcrop along Yadgar section in Muzaffarabad area were selected. The study area comprises of best outcrop for determining the geological characteristics, weathering conditions and lithological variations. Therefore, detailed engineering geological investigations were 

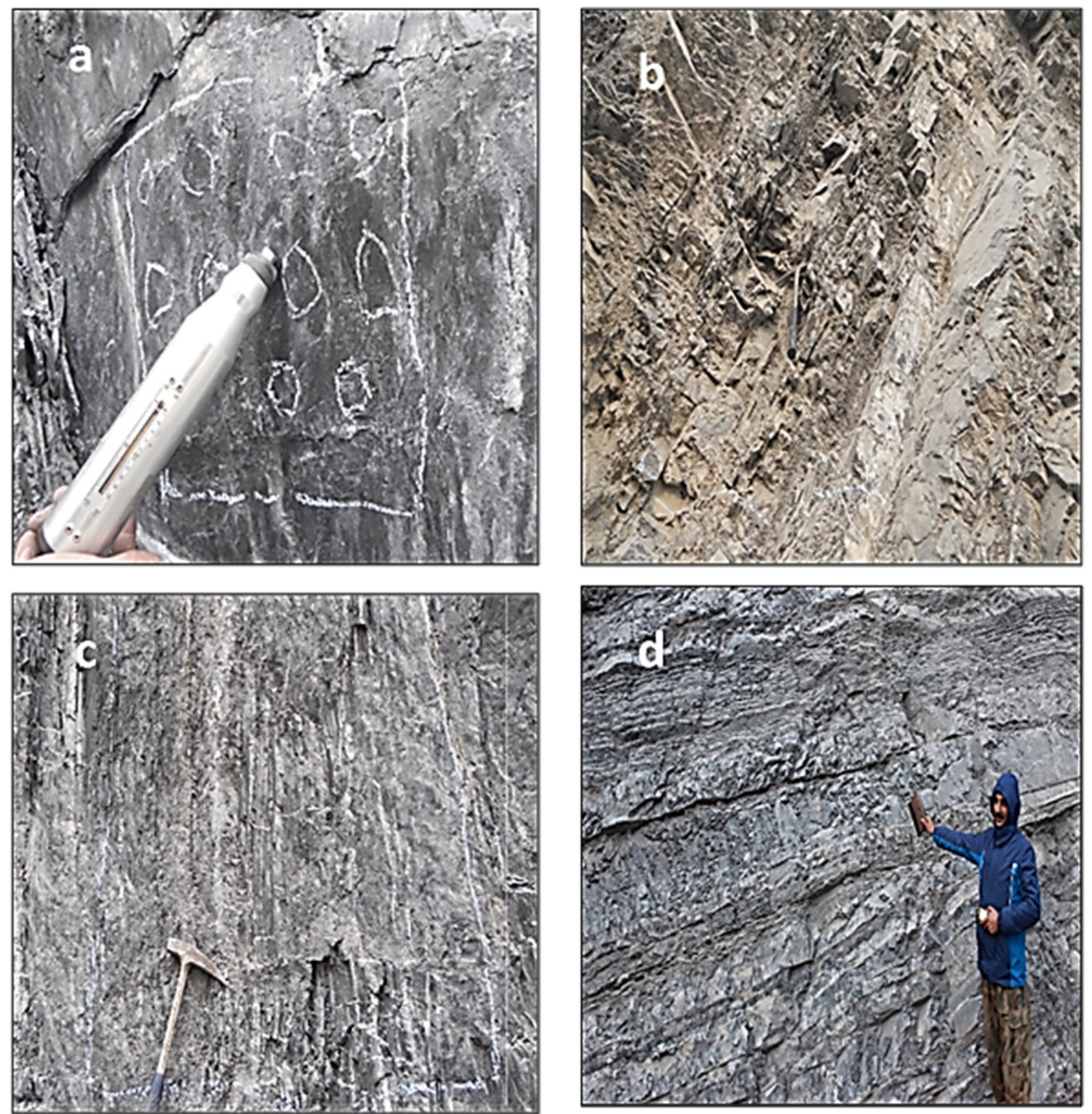

Fig. 3 (a) Measuring rebound with Schmidt hammer for UCS at selected point location, (b) Discontinuities along road cut section at Yadgar area. (c) Poor rock mass at the location Ca1. (d) Photograph shows less fair rock mass at location $\mathrm{Ca} 4$.

performed in order to document jointed slopes and discontinuity patterns of the rock masses in the present study (Fig. 3b). The description of rock mass characteristics from older rock units to younger rock units have been presented in this study in a sequential order. The estimation of RMR has been performed at 25 locations (Table 1).

\subsubsection{ABBOTTABAD FORMATION}

The Abbottabad Formation comprises of stromatolitic, cherty dolomites, white cherty and grey limestone with dark shales. At Yadgar area, lithological variations of the Abbottabad Formation has been divided into two parts for assessment of the carbon content greatly effects the RMR appraisals in engineering perspective. In this area, rock masses are intensely fractured and jointed due to the active MF. The RQD of the Abbottabad Formation is very low and is therefore classified as fair-poor rock (Fig. 3c). In this rock unit, observations were taken from about five locations ( $\mathrm{Ca} 1, \mathrm{Ca} 2, \mathrm{Ca} 3, \mathrm{Ca} 4, \mathrm{Ca} 5)$ based on different out crop conditions. According to the classification system, the RMR value of $\mathrm{Ca} 1$ and $\mathrm{Ca} 2$ are 40, 46 respectively (poor - fair rock). The UCS of $\mathrm{Ca} 1$ has moderate value and complete dry conditions whereas have smooth roughness in joints and very low RQD of its densely jointed pattern with less spacing in joint set. $\mathrm{Ca} 1$ and $\mathrm{Ca} 2$ consists of mainly dolomitic limestone with more carbon content in comparison with $\mathrm{Ca} 3, \mathrm{Ca} 4$, and $\mathrm{Ca} 5$. In fact, at these locations, the value of RQD is also very low, absence of aperture with no fill material and its UCS contributes little in 
Table 1 Calculated values of Rock Mass Rating (RMR) in the study area (Bieniawski, 1976).

\begin{tabular}{|c|c|c|c|c|c|c|c|c|c|c|c|c|}
\hline \multicolumn{2}{|l|}{ Location } & \multirow{2}{*}{$\begin{array}{c}\mathrm{R} 1 \\
\\
\\
4\end{array}$} & \multirow{2}{*}{$\begin{array}{c}\mathrm{R} 2 \\
\\
8\end{array}$} & \multirow{2}{*}{$\begin{array}{r}\mathrm{R} 3 \\
\\
\\
5\end{array}$} & \multicolumn{5}{|c|}{$\begin{array}{c}\text { R4 } \\
\text { Persistency Aperture } \\
\text { Roughness Filling weathering }\end{array}$} & \multirow{2}{*}{$\begin{array}{r}\text { R5 } \\
\\
15\end{array}$} & \multirow{2}{*}{$\begin{array}{c}\text { RMR } \\
\\
40\end{array}$} & \multirow{2}{*}{$\begin{array}{l}\text { Remarks } \\
\text { Poor }\end{array}$} \\
\hline \multirow{25}{*}{ 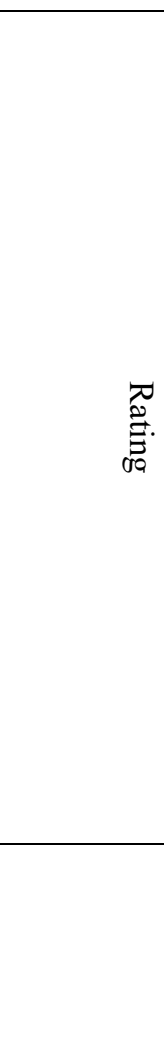 } & $\mathrm{Ca} 1$ & & & & 0 & 5 & 1 & 2 & 0 & & & \\
\hline & $\mathrm{Ca} 2$ & 7 & 3 & 10 & 0 & 1 & 3 & 2 & 5 & 15 & 46 & Fair \\
\hline & $\mathrm{Ca} 3$ & 12 & 3 & 5 & 1 & 4 & 3 & 6 & 5 & 15 & 54 & Fair \\
\hline & $\mathrm{Ca} 4$ & 12 & 13 & 5 & 0 & 1 & 1 & 2 & 3 & 15 & 52 & Fair \\
\hline & $\mathrm{Ca} 5$ & 7 & 8 & 8 & 0 & 0 & 5 & 0 & 3 & 15 & 46 & Fair \\
\hline & Th1 & 4 & 3 & 8 & 0 & 0 & 3 & 2 & 3 & 15 & 40 & Poor \\
\hline & Th2 & 7 & 3 & 8 & 4 & 1 & 3 & 2 & 3 & 15 & 45 & Fair \\
\hline & TL1 & 7 & 8 & 5 & 0 & 5 & 3 & 6 & 5 & 15 & 54 & Fair \\
\hline & TL2 & 12 & 8 & 10 & 0 & 1 & 3 & 6 & 5 & 15 & 60 & Fair \\
\hline & TL3 & 7 & 3 & 8 & 0 & 6 & 1 & 6 & 3 & 15 & 49 & Fair \\
\hline & TL4 & 7 & 8 & 5 & 1 & 6 & 3 & 2 & 5 & 15 & 52 & Fair \\
\hline & TL5 & 12 & 8 & 5 & 0 & 1 & 3 & 6 & 5 & 15 & 55 & Fair \\
\hline & Tml1 & 12 & 13 & 10 & 0 & 1 & 3 & 2 & 5 & 15 & 61 & Good \\
\hline & Tml2 & 7 & 3 & 10 & 0 & 1 & 3 & 2 & 5 & 7 & 38 & Poor \\
\hline & $\mathrm{Tml} 3$ & 12 & 17 & 8 & 0 & 1 & 1 & 2 & 3 & 15 & 59 & Fair \\
\hline & Tk1 & 4 & 8 & 8 & 0 & 0 & 3 & 2 & 5 & 15 & 45 & Fair \\
\hline & Tk2 & 12 & 13 & 8 & 0 & 5 & 3 & 6 & 5 & 15 & 67 & Good \\
\hline & Tk3 & 7 & 3 & 5 & 1 & 5 & 1 & 6 & 3 & 15 & 46 & Fair \\
\hline & Tk4 & 4 & 8 & 5 & 1 & 1 & 1 & 2 & 3 & 15 & 40 & Poor \\
\hline & Tk5 & 7 & 3 & 5 & 1 & 1 & 3 & 2 & 5 & 7 & 34 & Poor \\
\hline & Tm1 & 7 & 13 & 8 & 0 & 1 & 3 & 2 & 3 & 7 & 44 & Fair \\
\hline & $\mathrm{Tm} 2$ & 4 & 13 & 5 & 0 & 1 & 3 & 2 & 3 & 7 & 38 & Poor \\
\hline & Tm3 & 7 & 13 & 8 & 0 & 1 & 1 & 2 & 6 & 15 & 63 & Good \\
\hline & Tm4 & 7 & 8 & 5 & 1 & 1 & 1 & 2 & 3 & 15 & 43 & Fair \\
\hline & $\operatorname{Tm} 5$ & 4 & 13 & 8 & 0 & 1 & 1 & 2 & 3 & 15 & 57 & Fair \\
\hline
\end{tabular}

the $\mathrm{RMR}$ value. $\mathrm{Ca} 1$ and $\mathrm{Ca} 2$ approached $\mathrm{RMR}$ values as 40 and 46 have poor quality of rock mass. $\mathrm{Ca} 4$ has imposed strong rock strength. RQD of $\mathrm{Ca} 4$ was fair because of more spacing with rough condition of surface with respect to other previous conditions. The values of $\mathrm{UCS}$ at $\mathrm{Ca} 3$ and $\mathrm{Ca} 4$ are very high. Similarly, $\mathrm{Ca} 2$ and $\mathrm{Ca} 5$ have strong UCS whereas, $\mathrm{Ca} 1, \mathrm{Ca} 2$ and $\mathrm{Ca} 3$ have moderately strong UCS with very poor RQD but fair at Ca4 (Fig. 3d). Roughness was also low at $\mathrm{Ca} 1, \mathrm{Ca} 2$ and $\mathrm{Ca} 4$ in comparison to $\mathrm{Ca} 3$ and $\mathrm{Ca} 5$. The locations of $\mathrm{Ca} 3, \mathrm{Ca} 4$, and $\mathrm{Ca} 5$ have strong to very strong intact strength. It is due to their dry conditions, strong UCS with wide aperture of soft fillings with RQD is in fair quality. RMR of $\mathrm{Ca} 3, \mathrm{Ca} 4$ and $\mathrm{Ca} 5$ are 54, 52, 46 respectively, with a fair quality (Table 1). Over the full range of characterization, $\mathrm{Ca} 3$ has strong fair nature of rocks while remaining have fair to poor (Fig. 4a). The results of RMR values represents the Abbottabad Formation as disintegratedpoorly interlocked, heavily broken rock mass with a mixture or angular and rounded rock pieces. These conditions of the Abbottabad Formation may be due to the close proximity to MF.

\subsubsection{HANGU FORMATION}

At Yadgar section, Hangu Formation is exposed along the road. The rock mass of Hangu Formation is thinly and poorly exposed at some areas in Muzaffarabad. The Hangu Formation comprises of brecciated quartzite, carbonaceous shales, sandstones, limonite, fire clay, bauxite, coal seams and conglomerates. The observations were taken at two locations, Th1 and Th2. The RMR values are 40 to 45 indicating fair and poor rock (Table 1). The intact strength of Th1 is moderately strong. Similarly, Th2 is also considered strong rating. The aperture is very wide at Th1. Therefore, Th1 is categorized as poor rock (Fig. 4b). Whereas, at both locations, conditions of ground water and infill material are same. The persistency was observed higher at Th1. These values of RMR represents that these rock units are at the upper limit of disintegrated-poorly interlocked nature.

\subsubsection{LOCKHART LIMESTONE}

The Lockhart limestone is well exposed at Yadgar section close to the Muzaffarabad. The Lockhart Limestone comprises of limestone and subordinate shales. Five different locations were taken for systematic detailed observations includes T11, T12, 

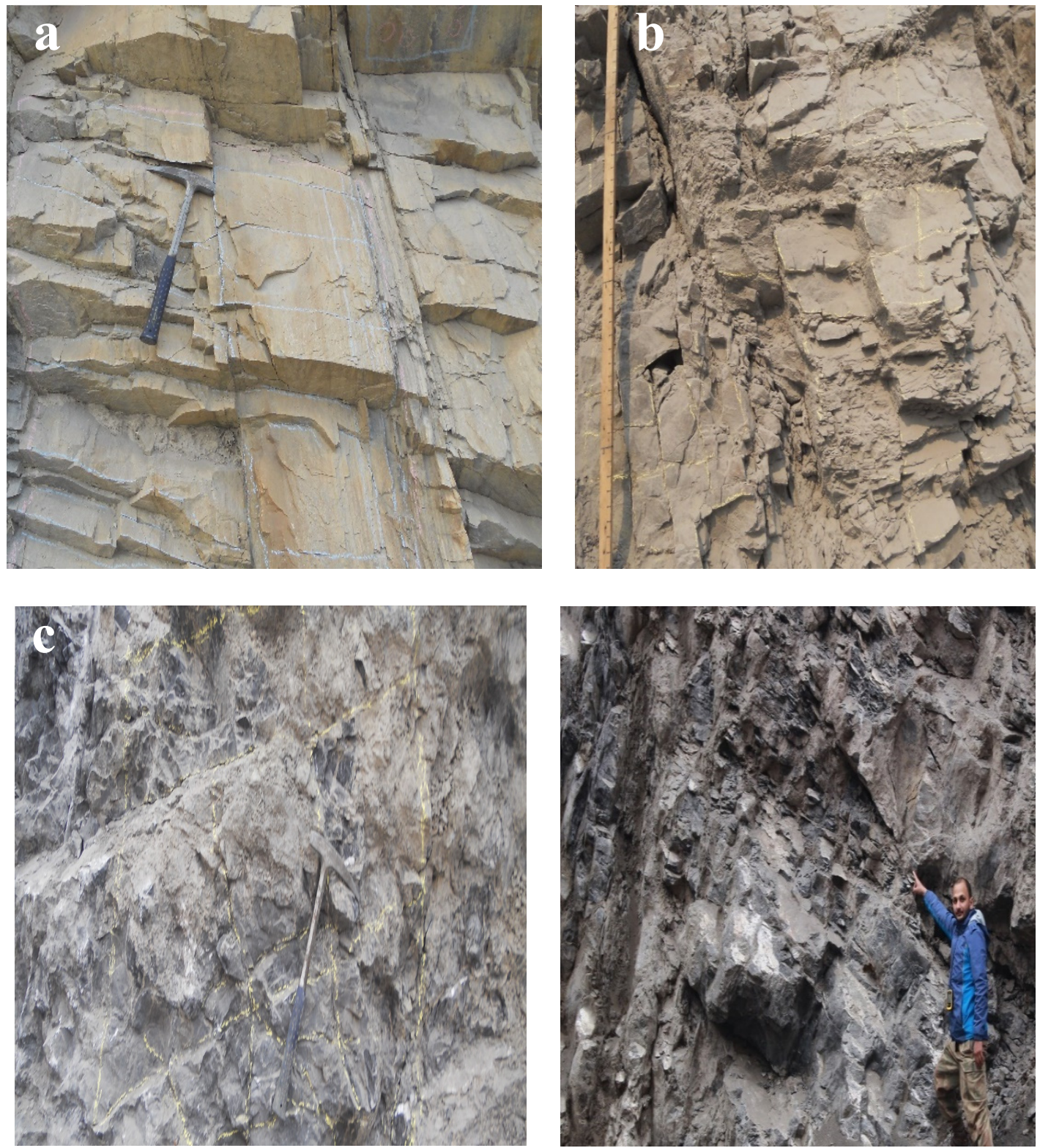

Fig. 4 (a) Fair rock mass at location Ca3. (b) Poor rock mass of Hangu Formation at Yadgar section. (c) Fair rock mass of Lockhart Limestone of Yadgar section. (d) Poor rock mass of Margala Hill Limestone with damp water condition.

T13, T14 and T15. At these locations RMR values range from 49 to 60 indicating overall fair rock quality (Fig. $4 c)$. T12 and T15 have excellent UCS ratings of 12 . T11, T13 and T14 contain mild strong limestone with UCS values of 7 . Whereas T12 and T15 have very high values of UCS. Only T13 possesses very poor RQD value and have wide opening and smooth-rough surface making it fair rock quality. While all the other parameters were similar for all samples of this formation. These values suggest the blocky disturbed behavior and improved RMR as compared to the Abbottabad and Hangu formations as moving away from fault.

\subsubsection{MARGALA HILL LIMESTONE}

Margala Hill Limestone is exposed laterally with road cuts of Yadgar section. Rock unit comprises of limestone with subordinate marl and shales. At the Yadgar section, Margala Hill Limestone is hard, massive and thin to thick bedded. The UCS of Margala Hill Limestone is high (100-250mpa) having good to poor RQD whereas water condition is dry to damp (Table 1). Because of these main parameters, the value of RMR varies from 61 to 38 . The values of RMR are 59 and 61 which are almost equal for the locations of Tml1 and Tml3 respectively. RQD at Tml1 is fair and good at Tml3 by consuming the RMR value of 17 . The condition of ground water as well as RQD varies at 


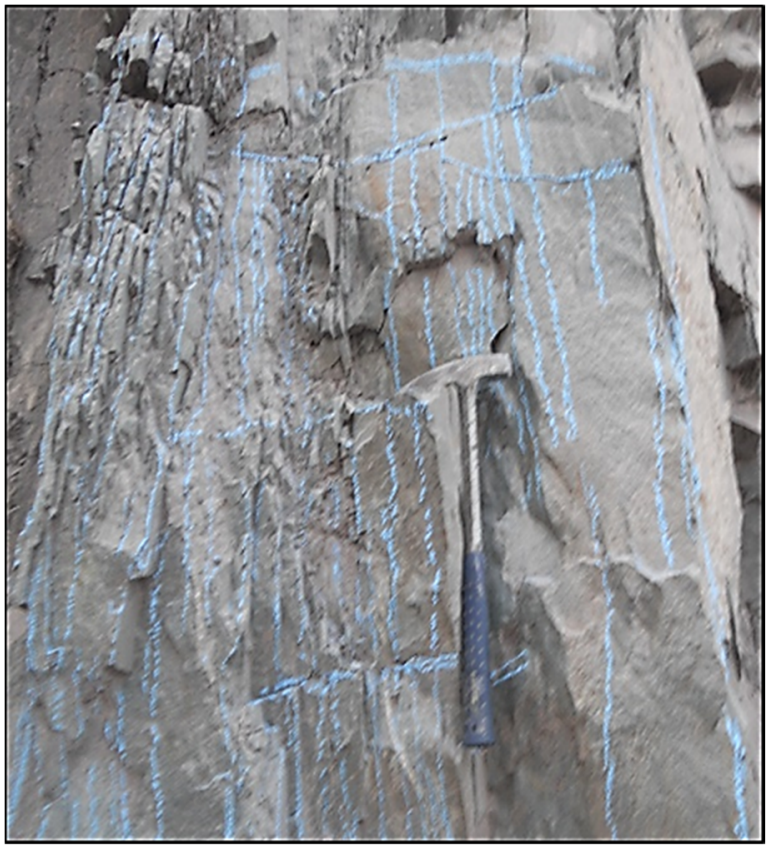

Fig. 5 Photograph shows poor rock mass at Tm2.

Tml2 with respect to Tml1 and Tml3 while, Tml2 has slightly moist condition (Fig. 4d). On the above estimations, the rock mass can be classified as good for Tml1, fair for $\mathrm{Tml} 3$ and poor at Tml2. Overall results of RMR values revealed improved rock quality as compared to previous discussed rock units as further moving away from MF.

\subsubsection{KULDANA FORMATION}

Kuldana Formation is exposed in Muzaffarabad along the Neelum valley road associated with Yadgar section. Here, the Chorgali Formation is recognized progressively through this formation. Kuldana Formation comprises of maroon to light red clay with subordinate green to greenish grey shales and finegrained sandstone. In this rock unit, five locations were considered for the detailed measurements, such as Tk1, Tk2, Tk3, Tk4 and Tk5. The values of RMR for Tk1, Tk2, Tk3, Tk4 and Tk5 were found 45 (fair), 67 (good), 46 (fair rock), 40 (poor) and 34 (poor rock), respectively (Table 1). Tk2 and Tk4 have fair to poor quality of RQD with rating 13 and 8 . Tk2 holds strong sandstone by fair RQD with constricted aperture, rough-slightly rough surface with good rock mass. Therefore, the infill and aperture ranges between 2 and 0 . Moreover, Tk3 has 5 rating in aperture and 6 in infilling. Further parameters like RQD, spacing and weathering conditions are consuming high rating to Tk3. Therefore, Tk3 takes maximum RMR value but both have a fair rock mass quality. Tk2 comprises good rock due to its very strong strength, fair RQD, very tight joints, slightly weathered and completely dry rock mass. Tk4 and Tk5 have poor rock quality because of low UCS and poor RQD. Tk5 has wide openings in soft fill material with saturated water condition. On the basis of RMR values this rock unit has been classified as disintegrated-poorly interlocked to blocky/disturbed and folded rock mass having intersecting discontinuity sets.

\subsubsection{MURREE FORMATION}

Murree Formation comprises of greenish sandstone, siltstone, shale and mudstone with cyclic depositional nature. Sandstone is fine to medium grained, jointed and fractured. Calcite and quartz veins are generally present in it. The formation is classified as fair rock, due to less strong intact strength, medium to high persistency, wide opening in soft fill material and damp condition. The RMR value of Tm1 is 44 (fair) and mainly comprises strong UCS, fair RQD and wide-moderate spacing in discontinuities and moderately weathered (Table 1). Value of RMR was found 63 (good rock), a high value at Tm3, while 38 (poor rock), a low value at $\operatorname{Tm} 2$ (Fig. 5). Values at $\mathrm{Tm} 1, \mathrm{Tm} 4$, and Tm5 indicate fair rock categories whereas, Tm2 shows the poor rock category. Good quality rock in the Murree Formation section was at Tm3 location. Based on RMR investigations Murree Formation has better rock mass properties as compared to previously discussed rock units. The Murree Formation has been classified as blocky/disturbed folded and/or faulted with angular blocks formed by many interscting discontinuity sets.

\subsection{GEOLOGICAL STRENGTH INDEX OF YADGAR SECTION}

Twenty-five locations were considered for performing GSI calculations as shown in Table 2, Table 3 and Figure 6a. As per the classification system for each location, $\mathrm{GSI}$ values at $\mathrm{Ca} 1, \mathrm{Ca} 2, \mathrm{Ca} 3, \mathrm{Ca} 4$ and $\mathrm{Ca} 5$ were $25 \pm 3,30 \pm 3,30 \pm 3,20 \pm 3$ and $35 \pm 3$, respectively (Table 2). The Jv values are 59 and 66.5 at $\mathrm{Ca} 1$ and $\mathrm{Ca} 4$. Whereas, SCR were 8 and 6 . Therefore, GSI of Ca1 and Ca4 were $25 \pm 3$ and $20 \pm 3$ respectively. Based on the characteristics both measuring points are placed in disintegrated-poorly interlocked heavily broken rock mass category (4) in GSI chart (Fig. 6a). Similarly, at $\mathrm{Ca} 2$ and $\mathrm{Ca} 3$ values of Jv are 49.17 and 50.8 respectively. Both locations also have similar SCR value 10. Value of GSI at location $\mathrm{Ca} 5$ is $35 \pm 3$ with JV of 26.5 .

GSI values of Th1 and Th2 are $29 \pm 3$ and $28 \pm 3$ respectively, is classified as Category 4 (Fig. 6b). The GSI values of T11 and T12 were similar, $45 \pm 3$ whereas, the values of $\mathrm{Jv}$ are 28.55 and 30.6 respectively. The locations T13 and T14 also have similar values as T11 and T12 (Table 2). In Lockhart Formation, T15 possess lowest value of GSI (35 \pm 3$)$ as compared to others because of its $\mathrm{Jv}$ value is 48 . Whole rock masses relevant to this formation in GSI chart, lies in category 4 . Tl5 is categorized as blocky/disturbed part category 3 due to its SR value of 28 . Nevertheless, these three rock masses possess fair, smooth, moderately weathered or altered surfaces respectively. 
Table 2 Calculated values of Geological Strength Index (GSI) in the study area (Sonmez and Ulusay, 1999).

\begin{tabular}{llllllrl}
\hline Location & JV & SR & Rr & Rw & Rf & SCR & GSI \\
\hline Ca1 & 59 & 9.8 & 1 & 5 & 2 & 8 & $25 \pm 3$ \\
Ca2 & 49.17 & 11.55 & 3 & 5 & 2 & 10 & $30 \pm 3$ \\
Ca3 & 50.8 & 11.1 & 3 & 5 & 2 & 10 & $30 \pm 3$ \\
Ca4 & 66.5 & 6.35 & 1 & 3 & 2 & 6 & $20 \pm 3$ \\
Ca5 & 26.5 & 22.5 & 5 & 3 & 2 & 10 & $35 \pm 3$ \\
Th1 & 34.68 & 17.8 & 3 & 3 & 2 & 8 & $29 \pm 3$ \\
Th2 & 35.92 & 17.1 & 1 & 3 & 2 & 6 & $28 \pm 3$ \\
T11 & 28.55 & 20.3 & 3 & 5 & 6 & 14 & $45 \pm 3$ \\
T12 & 30.6 & 19.9 & 3 & 5 & 6 & 14 & $45 \pm 3$ \\
T13 & 36.56 & 16.8 & 1 & 6 & 6 & 13 & $40 \pm 3$ \\
T14 & 50 & 24.18 & 3 & 3 & 6 & 12 & $40 \pm 3$ \\
T15 & 48 & 23.61 & 1 & 3 & 6 & 10 & $35 \pm 3$ \\
Tm11 & 18.01 & 29.2 & 3 & 6 & 2 & 11 & $40 \pm 3$ \\
Tm12 & 43.45 & 13.7 & 3 & 5 & 2 & 10 & $30 \pm 3$ \\
Tm13 & 12 & 36.31 & 3 & 6 & 2 & 6 & $32 \pm 3$ \\
Tk1 & 58 & 8.7 & 5 & 5 & 2 & 12 & $35 \pm 3$ \\
Tk2 & 23.51 & 24.5 & 3 & 5 & 6 & 14 & $45 \pm 3$ \\
Tk3 & 60 & 27.48 & 1 & 3 & 6 & 10 & $37 \pm 3$ \\
Tk4 & 50 & 24.18 & 5 & 5 & 2 & 12 & $40 \pm 3$ \\
Tk5 & 48 & 23.61 & 3 & 3 & 2 & 8 & $30 \pm 3$ \\
Tm1 & 22.2 & 25.5 & 3 & 5 & 2 & 10 & $35 \pm 3$ \\
Tm2 & 20 & 27.48 & 1 & 5 & 6 & 12 & $40 \pm 3$ \\
Tm3 & 13 & 35 & 3 & 6 & 6 & 15 & $50 \pm 3$ \\
Tm4 & 18 & 29.23 & 3 & 5 & 2 & 10 & $37 \pm 3$ \\
Tm5 & 16 & 31.33 & 3 & 6 & 2 & 11 & $40 \pm 3$ \\
\hline
\end{tabular}

Table 3 Definition of JCond89, after (Bieniawski, 1989; Palmstrom, 2005).

\begin{tabular}{lccc}
\hline Location & SCR & RQD/2 & GSI \\
\hline Ca1 & 8 & 18.5 & $25 \pm 3$ \\
Ca2 & 10 & 6.5 & $20 \pm 3$ \\
Ca3 & 10 & 8.5 & $20 \pm 3$ \\
Ca4 & 6 & 28 & $33 \pm 3$ \\
Ca5 & 10 & 22 & $30 \pm 3$ \\
Th1 & 8 & 11.5 & $18 \pm 3$ \\
Th2 & 6 & 10 & $15 \pm 3$ \\
T11 & 19.5 & $33 \pm 3$ \\
T12 & 14 & 16.75 & $30 \pm 3$ \\
T13 & 9.3 & $20 \pm 3$ \\
T14 & 14 & 25 & $35 \pm 3$ \\
T15 & 13 & 24 & $33 \pm 3$ \\
Tml1 & 32.5 & $43 \pm 3$ \\
Tm12 & 12 & 1 & $10 \pm 3$ \\
Tm13 & 10 & 40 & $48 \pm 3$ \\
Tk1 & 11 & 17.5 & $26 \pm 3$ \\
Tk2 & 10 & 25.5 & $37 \pm 3$ \\
Tk3 & 6 & 30 & $40 \pm 3$ \\
Tk4 & 12 & 25 & $35 \pm 3$ \\
Tk5 & 14 & 24 & $33 \pm 3$ \\
Tm1 & 10 & $35 \pm 3$ \\
Tm2 & 10 & 30 & $40 \pm 3$ \\
Tm3 & 8 & 38.75 & $50 \pm 3$ \\
Tm4 & 10 & 32.5 & $42 \pm 3$ \\
Tm5 & 12 & $55 \pm 3$ \\
\hline
\end{tabular}




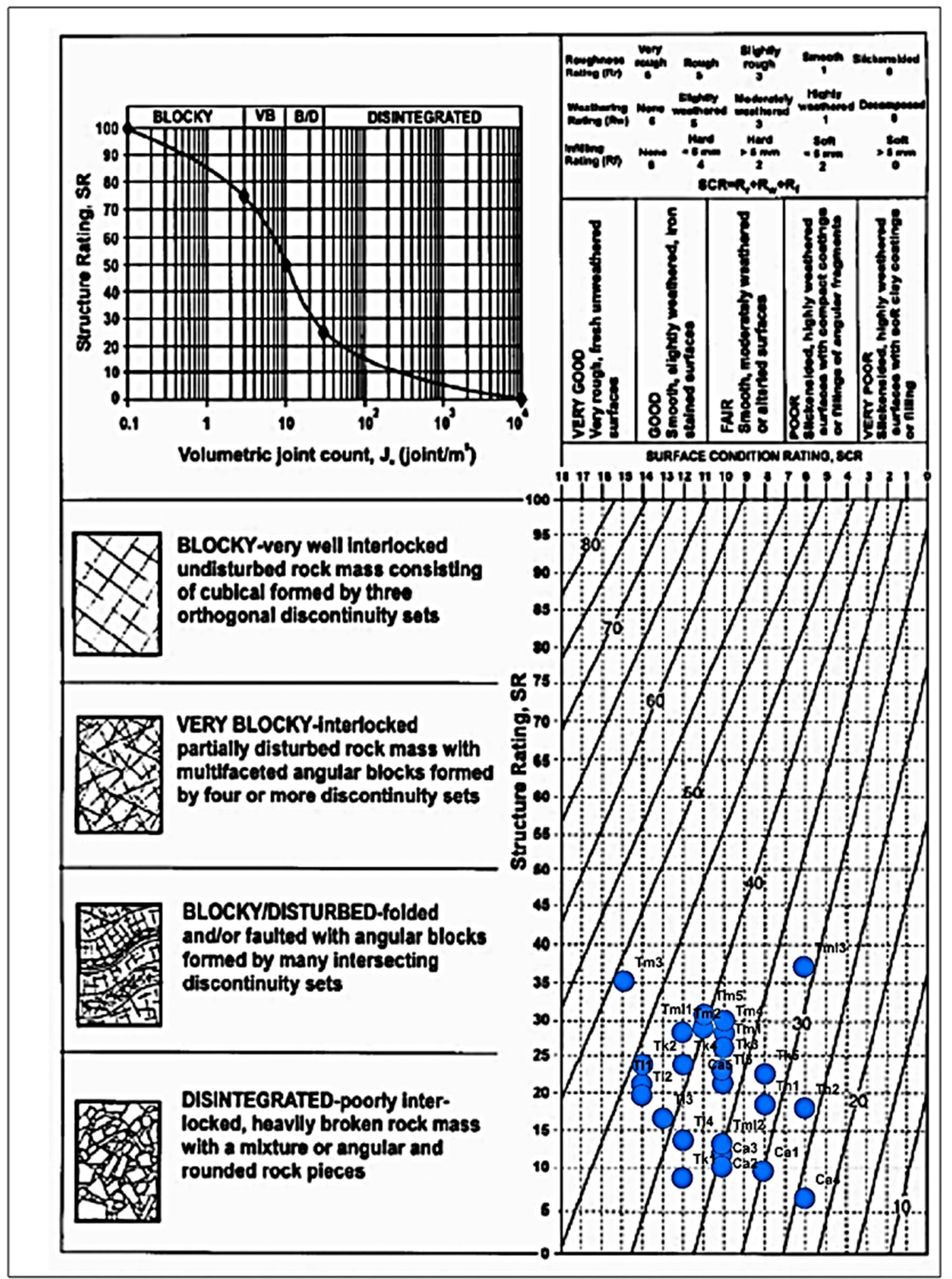

Fig. 6(a) Chart showing GSI values of Yadgar section in Muzaffarabad area Hoek and Brown (1997), Hoek et al. (1989).

GSI of all measured locations associated with Margala Hill Limestone is Tml1 $40 \pm 3$ due to Jv ratings 18.01 gives results of SR 29.2 and SCR is 11. However, Tml 2 and Tml 3 consumed GSI value $30 \pm 3$ and $32 \pm 3$ respectively. Tml 2 and $\mathrm{Tml} 3$ have Jv ratings are 43.45 and 12 gives SR of 13.7, 36.31 and SCR of
10, 6 respectively. Therefore, Tml1 and $\mathrm{Tml} 3$ were placed in category 3 in GSI chart. The rock masses of these two locations were classified as poor-fair surfaces. Tml2 was characterized in category 4 . The GSI values of rock masses of location Tk2, Tk3 and TK4 are $45 \pm 3,37 \pm 3$ and $40 \pm 3$ respectively, because 


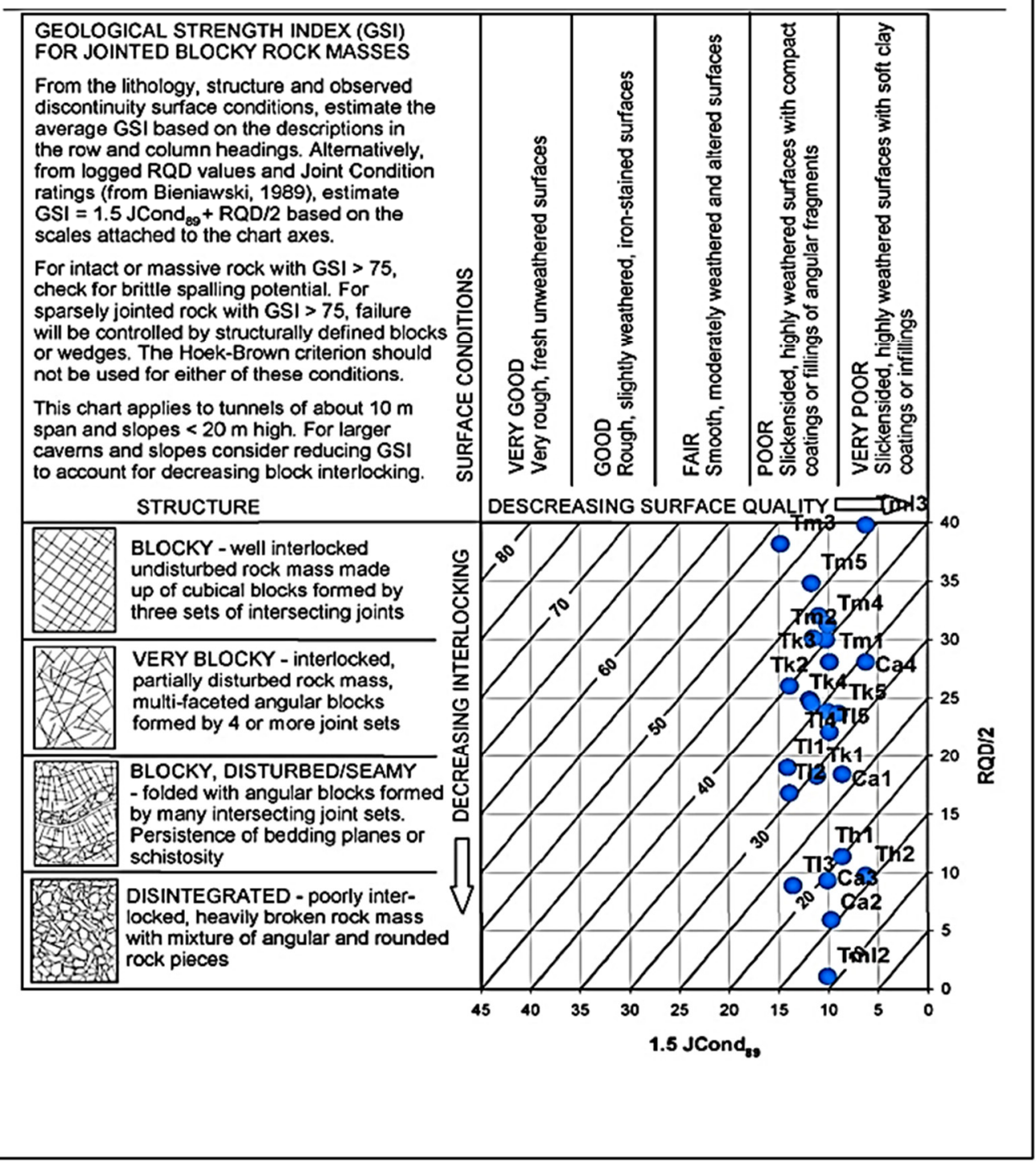

Fig. 6(b) Figure shows quantification of GSI by joint condition and RQD of Yadgar section (modified after (Hoek et al. 2013).

their Jv ratings are 23.51, 60 and 50. Similarly, their SR were 24.5, 27.48, 24.18 and SCR were 14, 10 and 12. These entire placed in category 4 , takes good condition of surface. Therefore, the locations Tk1 and Tk5 posed values of $35 \pm 3,30 \pm 3$. GSI values were different with each other and characterized in category 3 on GSI chart.

In Murree Formation, Tm2 and Tm5 contains same values of GSI by Jv ratings of 20 and 18 . Tm2 and Tm5 also have similar values of SCR as 12 and 10. Whereas Tm1 and Tm4 have GSI values $35 \pm 3$, $37 \pm 3$ respectively and having $\mathrm{Jv}$ values of 22.2 and 18 . The location of Tm3 posed GSI 50 \pm 3 , SR 31.33 and SCR 11, due to the Jv ratings of 16. All these locations which were associated with the Murree Formation categorized in category 3 .

\subsection{CHECK OF MAPPED GSI AGAINST QUANTIFIED GSI}

The mapped GSI values were crossed checked by anticipated calculation of quantified GSI values to verify the correlation factor of GSI against quantified GSI values. The quantified GSI values calculated from JCond89 and RQD by that placed contrary to ratings in Figure 6b. Figure 7 demonstrates that the correlation between quantified and mapped GSI ratings rationally near the good association for rough fit of GSI estimations.

Diverse estimations of GSI has been achieved (Table 3). Maximum GSI rating was found $50 \pm 3$ at Tm3. This indicates that the Tm3 possesses better nature of rock mass arranged very good interlocked undisturbed rock mass. $\mathrm{Ca} 4$ indicates minimal value 


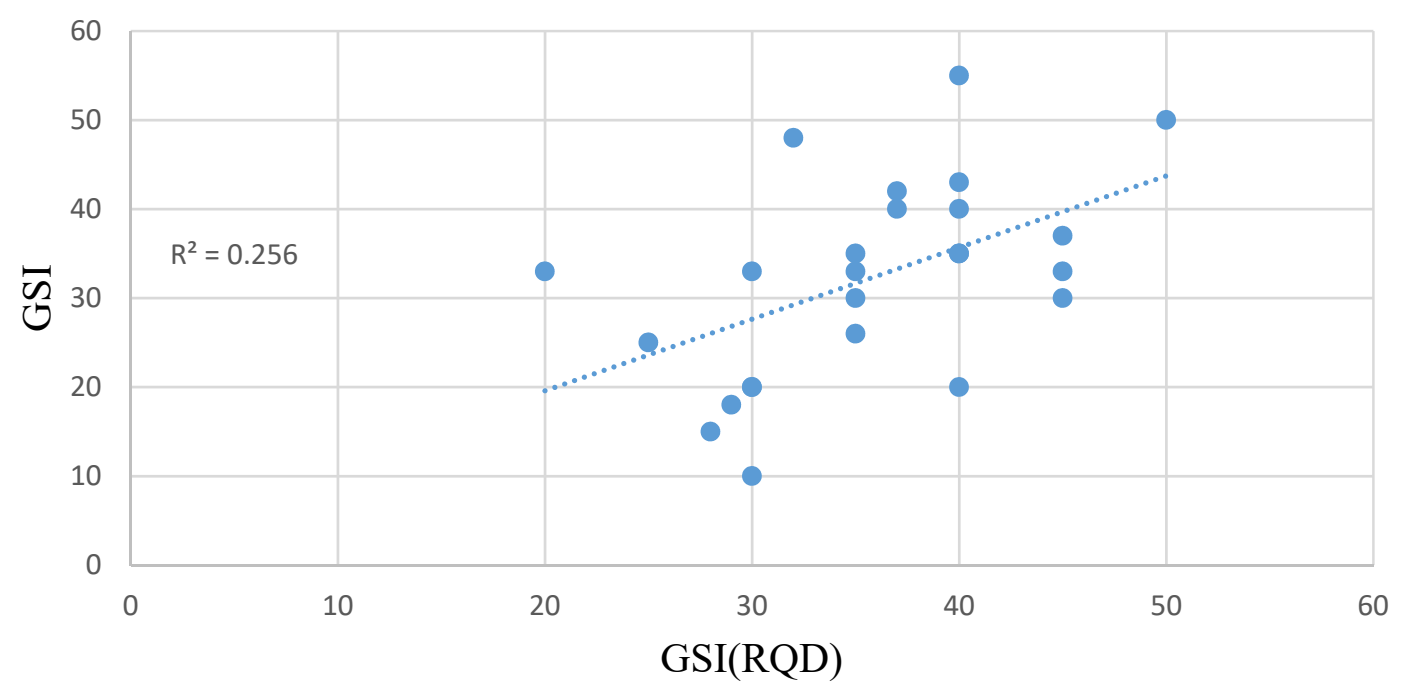

Fig. 7 Graph showing comparison between mapped GSI and GSI predicted by RQD.

because of its poor rock mass. Ca1, Th1 and Th2 also have poor rock masses.

According to the quantified GSI measurement Jcond89 and RQD the locations $\mathrm{Ca} 2, \mathrm{Ca} 3, \mathrm{Tl} 3$ and Th1 have same GSI value of $20 \pm 3$ and therefore can be classified as very poor rock masses. $\mathrm{Ca} 2, \mathrm{Ca} 3$ and $\mathrm{Tl} 3$ are characterized as disintegrated and poorly interlocked rocks. Whereas, Th1 can be placed in blocky/disturbed rock mass, based on its SCR rating 18. Remaining locations are characterized as blocky to very blocky rock mass.

\section{DISCUSSION}

Geological and geomechanical properties have been investigated in the Sub-Himalayan region of Yadgar section with the aim of evaluation of RMR and GSI. Geotechnical investigation of the area provides the assessment of rock mechanics and soil mechanics to understand the underneath condition of material. Rock mass classification systems are being utilized to deal with tunneling and surface characterization, particularly for the determination of support prerequisites. There are various methods to characterize and categorize the extensive bulk of rocks, known as geomechanical classifications. RMR proposed by Bieniawski (1989) has been established during field and laboratory study, with the inclusion of site slope data. GSI is the other technique after Hoek and Brown (1976), enhanced by Sonmez and Ulusay (1999), describe the system for the assessment of diminishment in the quality of rock mass in the different geological conditions. The GSI estimations were associated with both the degree of fracturing and fracture surface condition.

Initially twenty unique classifications were arranged into the original GSI system Hoek and Brown (1976) with naked eye observations with respect to the rock mass and surface properties of discontinuities. GSI values ranging between 20 and 50 were evaluated. Additionally, two rock mass classes foliated/laminated rock structures in placed rock were also included in GSI classification by Hoek et al. (1989). In this manner, Sonmez and Ulusay (1999), made an effort to introduce numerical approach to estimate GSI as contributory application of the GSI framework which has been used in present study because of the nature of rocks are deteriorated-blocky and more extremely poor rock masses. RQD played a major role as a part of rock mass framework. RQD was not utilized for poor to very poor rock masses because in trouble of its measurements where its readings are zero. Joint condition rating (JCond89) by Bieniawski (1976), RQD by Palmstrom (2005). criteria improved GSI framework to check the rock mass rating validity crossly.

Zhang et al. (2019), performed a quanitative correlation assessment between RMR and GSI and found that their proposed correlation showed good performance. Ali et al. (2014), correlate Q value, GSI and RMR to characterized rock mass for diversion tunnels at Diamer Basha, dam Pakistan and was found to have a greater degree of confidence with a higher correlation coefficient $(\mathrm{R} 2=0.84)$.

Singh et al. (2013), investigated RMR and GSI of rock units from central Nepal Lesser Himalaya and found that rock mssess have poor to very good quality (36-82) and GSI $13.5 \pm 3$ to $58 \pm 3$ (poor to good). These rocks showed better GSI and RMR values as compared to our investigations (RMR; 34-67; GSI: $20 \pm 3-50 \pm 3$ ). Similarly, to Singh et al. (2013), our investigations also revealed positive corealtion between GSI and RMR.

Singh et al. (2020), performed analytical and numerical stability analysis in Garhwal Himalaya, India and found that the RMR and GSI resulted almost same characteristics and revealed that rocks are mostly 


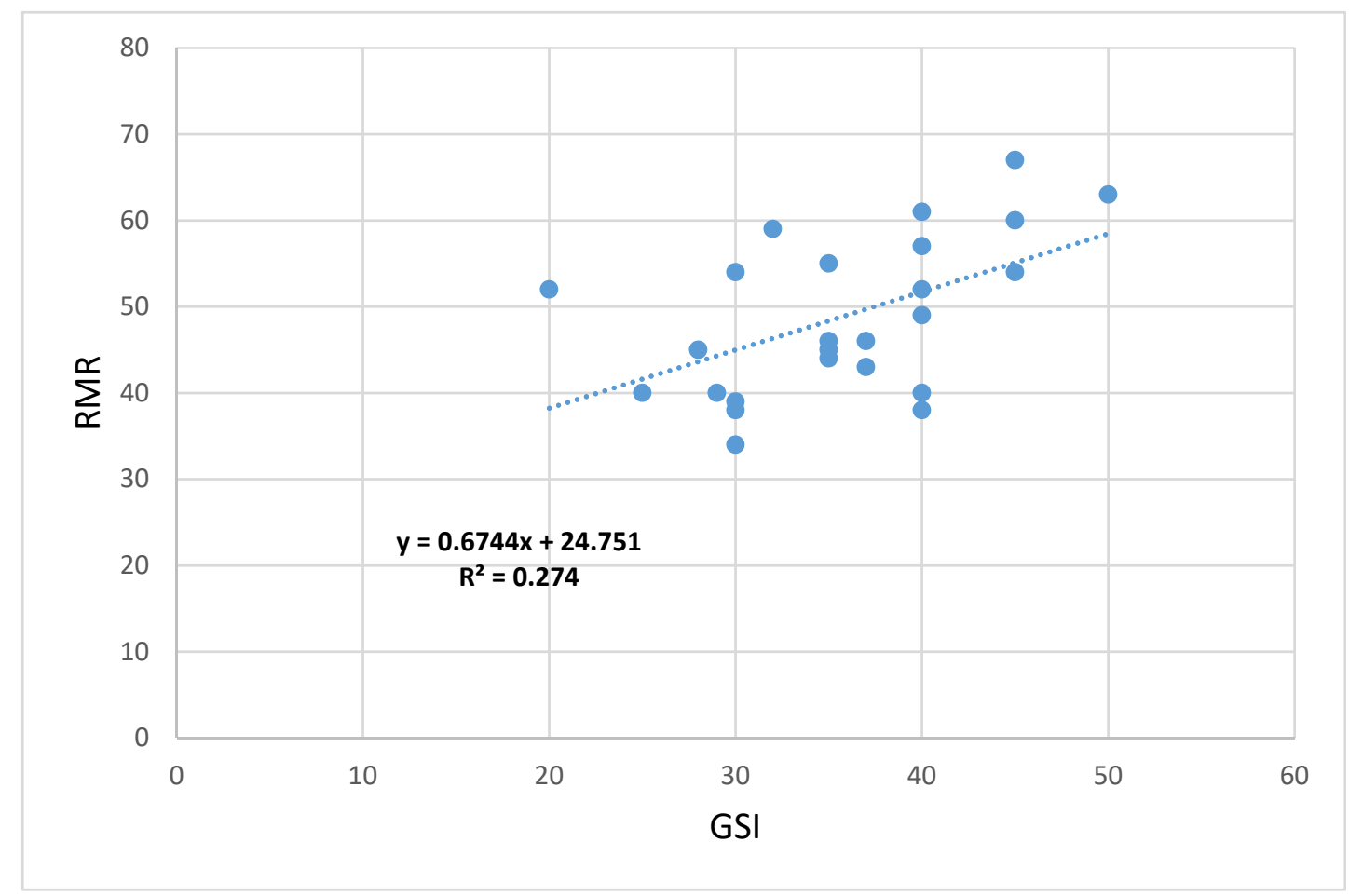

Fig. 8 The relationship between RMR/GSI and Lithology.

blocky with fair and good surface condition contrary to our investigations as rocks are of poor to fair conditions.

Ansari et al. (2019), found a linear relationship between GSI and RMR for active Himalayan region of Lesser Himalaya. RMR values suggests that the rocks along road corridor have fair to qood quality as compared to our study (poor to fair).

Kundu et al. (2017), performed stability analysis in Himachal Pradesh, India and found that RMR depicts poor rock mass quality which are somewhat in line with our investigations.

The description of rock mass characteristics from older rock units to younger rock units were presented briefly in the sequential order. The estimation of RMR has been performed for 25 locations (Table 1). The weak and positive correlation was found between RMR and GSI having coefficient of determination $\left(R^{2}=0.274\right)$. Nevertheless, the deviation of trend was shown by weak rocks of dolomitic limestone (Abbottabad Formation), sandstone (Hangu Formation), sandstone (Kuldana Formation) and limestone (Margala Hill Limestone.

Tk2 contained maximum RMR rating 67 (good rock) and $\mathrm{Tk} 5$ have 34 (poor rock) as shown in Figure 9. The poor rock classes were characterized by Ca1, Ca2, Th1, Tml2, Tk4, Tk5 and Tm2. The fair rocks were shown by $\mathrm{Ca} 3, \mathrm{Ca} 4, \mathrm{Ca} 5, \mathrm{Th} 2, \mathrm{Tl1}, \mathrm{Tl} 2$, T13, T14, T15, Tml3, Tk1, Tk3, Tm1, Tm4, and Tm5. Good quality rocks were Tml1, Tk2, and Tm3. Very good rock mass value was characterized by Tk2 as compared to other good rock masses in the study area. Both RMR and GSI turns out to be maximum when lithology is competent and massive, while, less competent and thinly bedded rock takes less values (Fig. 8).

\section{CONCLUSION}

The study indicates that the rock masses of Yadgar section Muzaffarabad have RMR values ranging between 34 to 67 (poor to good). Similarly, GSI value shows that the rocks are fair to good (35 \pm 3 to $50 \pm 3$ ) except highly fractured dolomitic limestone. The types of the rocks exposed in the Yadgar section, the dolomite falls in poor rock type having lowest RMR and GSI values. In contrary, limestone and sandstone are fair and good type of rock with moderate ratings of RMR and GSI values. The limestone was found as very good rock mass with contrasting rock types in the considered area. On contrary, the dolomite of the Abbottabad Formation are poor rock masses having lowest intact strength, very poor RQD, and very close discontinuity spacing. The sandstone of the Hangu Formation and the Kuldana Formation are fair rock type with fractured rock masses having very lowest RMR and GSI values. The Lockhart Limestone, Margala Hill limestone and sandstone of the Murree Formation are fair rock types with moderate RMR and GSI values. In addition, Margala Hill Limestone and sandstone of the Kuldana Formation are very good rock masses at some locations having relatively high RMR and GSI values. The result of GSI shows inverse variation relationship between the rock types as compared to RMR. The result reveals that the Cambrian Abbottabad Formation is vulnerable in the Yadgar section with extremely poor RQD, lowest UCS and closely spaced discontinuities. The analysis shows that there is 


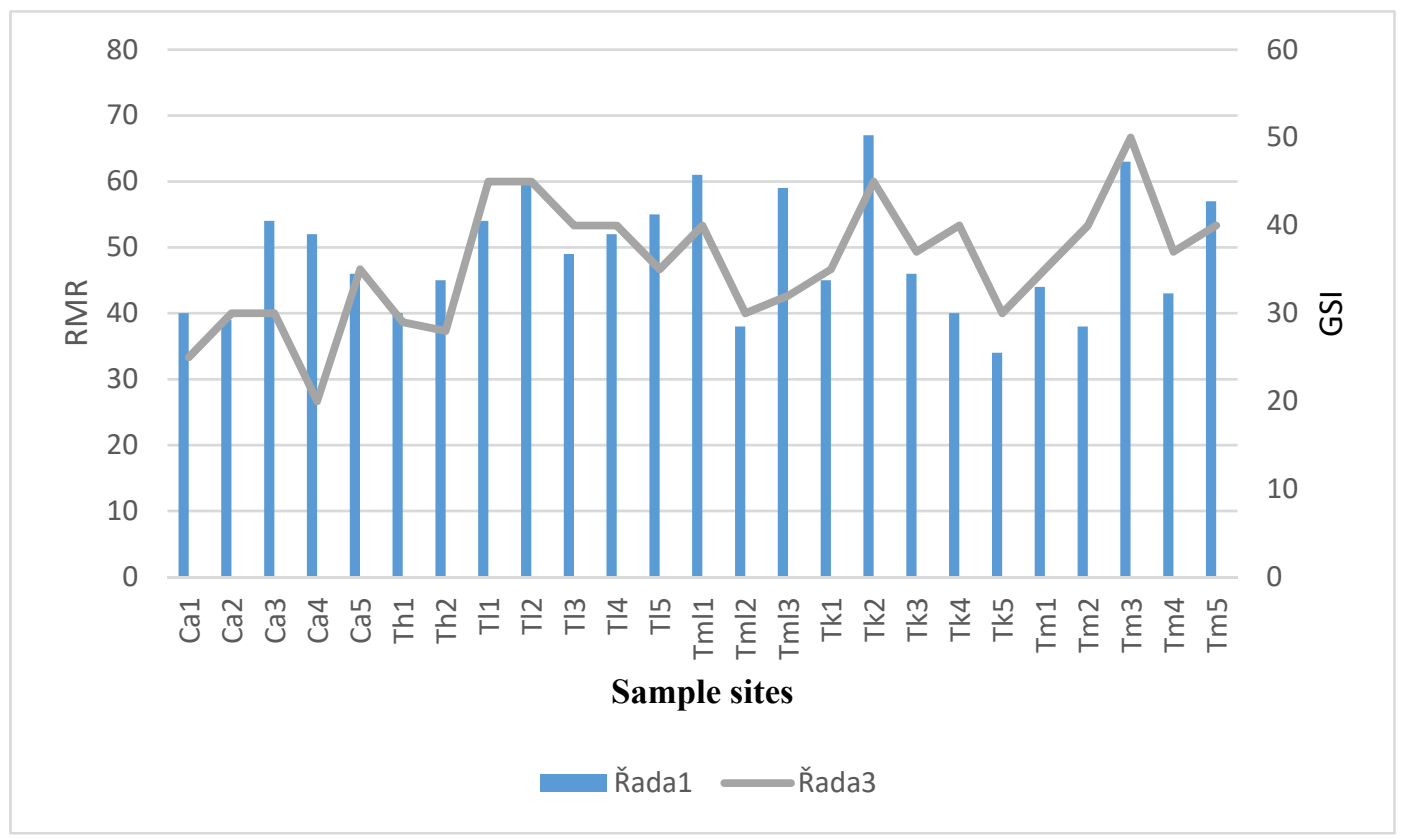

Fig. 9 Relationship between RMR and GSI of different rock samples.

positive relationship between GSI and RMR for rock masses of Yadgar section.

\section{REFERENCES}

Ali, W., Mohammad, N. and Tahir, M.: 2014, Rock mass characterization for diversion tunnels at Diamer Basha Dam, Pakistan-a design perspective. Int. J. Sci. Eng. Technol., 3, 10, 1292-1296.

Ambraseys, N. and Jackson, D.: 2003, A note on early earthquakes in northern India and southern Tibet. Curr. Sci. India, 84, 4, 570-582.

Ansari, T.A, Sharma, K.M. and Singh, T.N.: 2019, Empirical slope stability assessment along the road corridor NH-7, in the lesser Himalayan. Geotech Geol Eng, 37, 6, 5391-5407. DOI: 10.1007/s10706-019-00988-w

Armbruster, J, Seeber, L and Jacob, K.B.: 1978, The northwestern termination of the Himalayan mountain front: active tectonics from micro earthquakes. J. Geophys. Res., 83, B1, 269-282. DOI: 10.1029/JB083iB01p00269

Avouac, J.P., Ayoub, F., Leprince, S., Konca, O. and Helmberger. D.: 2006. The 2005, Mw 7.6 Kashmir earthquake: Sub-pixel correlation of ASTER images and seismic waveforms analysis. Earth Plant. Sci. Lett., 249, 3-4, 514-528.

DOI: $10.1016 /$ j.epsl.2006.06.025

Baig, M.S. and Lawrence, R.D.: 1987, Precambrian to Early Paleozoic orogenesis in the Himalaya. Kashmir J. Geol., 5, 1-22.

Bar, N. and Barton, N.: 2017, The Q-slope method for rock slope engineering. Rock Mech Rock Eng, 50, 12, 3307-3322. DOI: 10.1007/s00603-017-1305-0

Bhatta, T.C.: 2006, Rock slope stability of right bank of dam area, middle Marsyangdi hydroelectric project Lumjung District, Central Nepal. M.Sc. Thesis, Central Department of Geology, Tribhuvan University.
Bieniawski, Z.T.: 1976, Rock mass classification in rock engineering. In Bieniawski, Z.T., ed., Proceed. of the Symposium on Exploration for Rock Engineering, CapeTown, Balkema, Rotterdam, 1, 97-106.

Bossart, P., Dietrich, D., Greco, A., Ottiger, R. and Ramsay, J.G.: 1988, The tectonic structure of Hazara Kashmir Syntaxis, southern Himalayas, Pakistan. Tectonics, 7, 273-297. DOI: 10.1029/TC007i002p00273

Cai, M., Kaiser, P.K., Uno, H., Tasaka, Y. and Minami, M.: 2004, Estimation of rock mass deformation modulus and strength of jointed hard rock masses using the GSI system. Int. J. Rock Mech. Min. Sci., 41, 1, 3-19. DOI: 10.1016/S1365-1609(03)00025-X

Calkins, J.A., Offield, T.W., Abdullah, S.K.M. and Ali, S.T.: 1975, Geology of the southern Himalaya in Hazara, Pakistan, and adjacent areas. US Geological Survey Professional Paper, 716-c, 29.

Greco, A.: 1991, Stratigraphy, metamorphism and tectonics of the Hazara-Kashmir Syntaxis area. Kashmir J. Geol., 8 and 9, 39-66.

Gupta, V., Bhasin, R.K., Kaynia, A.M., Kumar, V., Saini, A.S., Tandon, R.S. and Pabst, T.: 2016, Finite element analysis of failed slope by shear strength reduction technique: a case study for Surabhi Resort Landslide, Mussoorie township, Garhwal Himalaya. Geomatics Nat Hazards Risk, 7, 5, 1677-1690. DOI: $10.1080 / 19475705.2015 .1102778$

Hoek, E. and Brown, E.T.: 1997, Practical estimates or rock mass strength. Int. J. Rock Mech. Min. Sci., 34, 8, 1165-1186. DOI: 10.1016/S1365-1609(97)80069-X

Hoek, E. and Brown, E.T.: 2019, The Hoek-Brown failure criterion and GSI-2018 edition. J. Rock Mech. Geotech. Eng., 11, 3, 445-463.

DOI: 10.1016/j.jrmge.2018.08.001

Hoek, E, Carter, T.G, Diederich, M.S.: 2013, Quantification of the Geological Strength Index chart. 47th US Rock Mechanics/Geomechanics Symposium, San Francisco, CA, USA. 
Hoek, E., Marinos, P. and Benissi, M.: 1989, Applicability of the Geological Strength Index (GSI) classification for very weak and sheared rock masses. The case of the Athens schist formation. Bull. Eng. Geol. Environ., 57, 2, 151-160. DOI: 10.1007/s100640050031

Kazmi, A.H. and Jan, M.Q.: 1997, Geology and tectonics of Pakistan: Graphics Publishers, Karachi, Pakistan, 554 pp.

Kim, B.H., Cai, M., Kaiser, P.K. and Yang, H.S.: 2007, Estimation of block sizes for rock masses with nonpersistent joints. Rock Mech. Rock Eng., 40, 2, 169192. DOI: $10.1007 / \mathrm{s} 00603-006-0093-8$

Kumar, G.: 1971, Geology and sulfide mineralization in the Pokheri Area Chaoli District, Uttar Pradesh. Geological Survey of India Miscellaneous Publication, 16, 92-128.

Kundu, J., Sarkar, K., Tripathy, A. and Singh, T.N.: 2017, Qualitative stability assessment of cut slopes along the National Highway-05 around Jhakri area, Himachal Pradesh, India. Earth Syst. Sci., 126, 8, 1-15. DOI: 10.1007/s12040-017-0893-0

Mahanta, B., Singh, H.O., Singh, P.K., Kainthola, A. and Singh, T.N.: 2016, Stability analysis of potential failure zones along NH-305 India. Nat. Hazards, 83, 3, 1341-1357. DOI: $10.1007 / \mathrm{s} 11069-016-2396-8$

Nakata, T., Tsutsumi, H., Khan, S.H. and Lawrence, R.D.: 1991, Vol. 141 of Active faults of Pakistan: Map sheet and inventories. Spec. publ. 21, Hiroshima Univ., 141.

Palmstrom, A.: 2005, Measurement and correlation between block size and RQD. Tunn. Undergr. Space Technol., 20, 4, 362-377. DOI: 10.1016/j.tust.2005.01.005

Petley, D., Dunning, S., Rosser, N. and Kausar, A.B.: 2006, Incipient landslides in the Jhelum Valley, Pakistan following the $8^{\text {th }}$ October 2005 earthquake. In: Disaster Mitigation of Rock Flows, Slope Failures and Landslides. Universal Academy Press, 1-9.

Riaz, M.T., Basharat, M., Hameed, N., Shafique, M. and Luo, J.: 2018, A data-driven approach to landslidesusceptibility mapping in mountainous terrain: case study from the Northwest Himalayas, Pakistan. Nat. Hazards Rev., 19, 4, 05018007. DOI: $10.1061 /(A S C E) N H .1527-6996.0000302$

Russo, G.: 2009, A new rational method for calculating the GSI. Tunn. Undergr. Space Technol., 24, 1, 103-111. DOI: 10.1016/j.tust.2008.03.002

Rustam, M.K., Khan, M.S. and Umar, F.: 2003, Study of shallow geological structures in the core of Hazara Kashmir Syntaxis based on residual gravity data in Azad Jammu and Kashmir Pakistan. Geol. Bull. Punjab Univ., 8, 35-42.

Seeber, L. and Armbruster, J.: 1979, Seismicity of the Hazara Arc in northern Pakistan: decollement vs. basement faulting. In Geodynamics of Pakistan, A. Farah and K.A. Dejong (eds.). Geological Survey of Pakistan, Quetta, 131-142.

Sen, Z. and Bahaaeldin, H.S.: 2003, Modified rock mass classification system by continuous rating. Eng. Geol., 67, 269-280. DOI: 10.1016/S0013-7952(02)00185-0

Singh, R.P., Dubey, C.S., Singh, S.K., Shukla, D.P., Mishra, B.K., Taj-bakhsh, M., Ningthoujam, P.S., Sharma, M. and Singh, N.: 2013, A new slope mass rating in mountainous terrain, Jammu and Kashmir Himalayas: application of geophysical technique in slope stability studies. Landslides, 10, 3, 255-265.

DOI: $10.1007 / \mathrm{s} 10346-012-0323-\mathrm{y}$
Singh, H.O., Ansari, T.A., Singh, T.N. and Singh, K.H.: 2020, Analytical and numerical stability analysis of road cut slopes in Garhwal Himalaya, India. Geotech. Geol. Eng., 38, 4811-4829.

DOI: $10.1007 / \mathrm{s} 10706-020-01329-\mathrm{y}$

Singh, J.L. and Tamrakar, N.K.: 2013, Rock mass rating and geological strength index of rock masses of ThopalMalekhu river areas, central Nepal Lesser Himalaya. Bulletin of the Department of Geology, 16, 29-42. DOI: $10.3126 /$ bdg.v16i0.8882

Solanki, A., Gupta, V., Bhakuni, S.S., Ram, P. and Joshi, M.: 2019, Geological and geotechnical characterisation of the Kho-tila landslide in the Dharchula region, NE Kumaun Himalaya. J. Earth Syst. Sci., 128, 4, 86. DOI: $10.1007 / \mathrm{s} 12040-019-1106-9$

Sonmez, H. and Ulusay, R.: 1999, Modification to the Geological Strength Index (GSI) and their Applicability to stability of Slopes. Int. J. Rock Mech. Min. Sci., 36, 743-760.

DOI: $10.1016 / \mathrm{S} 0148-9062(99) 00043-1$

Vásárhelyi, B. and Bögöly, G.: 2019, New method for determining the Geological Strength Index (GSI) value of boreholes. Geotechnical Challenges in KARST ISRM Specialised Conference, Omiš - Split, Croatia, 11.-13.04.2019.

Wadia, D.N.: 1928, The geology of the Poonch State (Kashmir) and adjacent portion of the Punjab. Geological Survey of India, Memoirs, 51, 185-370.

Wadia, D.N.: 1931, The syntaxis of the north-west Himalaya-its rocks, tectonics, and orogeny. Rec Geol Surv India, 65, 189-220.

Winn, K. and Wong, L.N.Y.: 2019, Quantitative GSI determination of Singapore's sedimentary rock mass by applying four different approaches. Geotech. Geol. Eng., 37, 3, 2103-2119.

DOI: $10.1007 / \mathrm{s} 10706-018-0748-8$

Yeats, R.S., Parsons, T., Hussain, A. and Yagi, Y.: 2006, Stress changes with the 8 October 2005 Kashmir earthquake, Lessons for the future. In: Kausar A.B., Karim T., Khna T. (eds), Extended abstracts. International Conference on 8 October 2005 Earthquake in Pakistan: Its implications and hazard mitigation. Geological Survey of Pakistan, Islamabad, 16-17.

Zhang, Q., Huang, X., Zhu, H. and Li, J.: 2019, Quantitative assessments of the correlations between rock mass rating (RMR) and geological strength index (GSI). Tunn. Undergr. Space Technol., 83, 73-81. DOI: $10.1016 /$ j.tust.2018.09.015 